\title{
Outbreak of intestinal amoebiasis among men who have sex with men, Barcelona (Spain), October 2016 and January 2017
}

L Escolà-Vergé ${ }^{1}$, M Arando $^{2}$, M Vall ${ }^{2}$, R Rovira ${ }^{2}, M_{\text {Espasa }}{ }^{3}$, E Sulleiro $^{3}$, P Armengol ${ }^{2}$, F Zarzuela $^{3}$, M Barberá $^{2}$

1. Department of Infectious Diseases, Hospital Universitari Vall d’Hebron, Barcelona, Spain

2. Sexually Transmitted Infections Unit (Drassanes). Department of Infectious Diseases, Hospital Universitari Vall d'Hebron, Barcelona, Spain

3. Microbiology Department, Hospital Universitari Vall d'Hebron, Barcelona, Spain

Correspondence: María-Jesús Barberá (mbarbera@vhebron.net)

Entamoeba histolytica has been recently recognised as an emerging sexually transmissible pathogen in men who have sex with men (MSM), causing sporadic outbreaks in countries where it is not endemic. Here we report two closed clusters of invasive amoebiasis occurring in Barcelona, Spain, in October 2016 (four cases) and in January 2017 (four cases).

Four cases of intestinal amoebiasis in men who have sex with men (MSM) were diagnosed within two consecutive days in October 2016 and another four cases in a period of two weeks in January 2017 (three of them on the same day), in Barcelona (Spain). We provide a description of epidemiological and clinical features of these eight patients and discuss the characteristics of this potentially re-emerging infection in the MSM population.

\section{Case Series}

All eight patients were MSM and presented with proctocolitis to a referral clinic for sexually transmitted infections (STIs) in Barcelona (Table). Mean age at diagnosis was 41.5 years (range: $21-56$ years). Four were HIVpositive, all with a CD4+- T cell count above $500 / \mathrm{mm}_{3}$. Regarding clinical manifestations, five patients had abdominal pain, four had diarrhoea with mucus, three had proctitis, two had dysentery, one had diarrhoea without mucus, and only one had fever. Mean duration of symptoms was 4 days (range: 2-10 days).

Fresh stool mount microscopic examination was positive for Entamoeba histolytica/dispar/moshkovskii complex trophozoites in three patients. In all eight patients, E. histolytica-specific adhesion antigen was detected by ELISA (Entamoeba CELISA Path, Cellabs). Bacterial faecal cultures for Salmonella, Shigella, Yersinia, Aeromonas, Campylobacter, Vibrio and E. coli were done for all patients and were positive for Shigella flexneri in two. Serum detection of E. histolytica antibody IgG by ELISA (NovaLisa Entamoeba histolytica IgG, NovaTec Immunodiagnostica GmbH, Dietzenbach, Germany) was performed in four patients to exclude extraintestinal dissemination and was negative in all (absorbance index $<0.9$ ).

Surprisingly, no epidemiological relationship among any of the patients was found. The only common factor was that two of them had recently travelled to the United Kingdom (UK), and that all of them had practiced oral-anal sex. Seven patients had between 1 and 30 sexual contacts in the 3 months before diagnosis, and one reported 100 contacts. Contact tracing was only possible for four patients. One patient recalled two non-infected sexual contacts (microscopy and $E$. histolytica-antigen detection in the contacts were negative) and another sexual contact in the UK who had travelled to Brazil and been diagnosed with amoebiasis before him. Two patients had asymptomatic stable partners with a negative faecal screening, and one patient had three contacts that could be reached, two not infected and one with a positive faecal screening but asymptomatic.

Five patients recovered after treatment with metronidazole followed by paromomycin, and three patients required repeated treatment due to poor adherence to paromomycin.

\section{Discussion}

E. histolytica infection (EHI) can range from asymptomatic infection to invasive intestinal or extra-intestinal disease, with the most frequent manifestations being amoebic colitis, as in our eight cases, and liver abscess $[1,2]$. The diagnosis should be confirmed by 
Epidemiological information for two clusters sexually transmitted amoebiasis in men who have sex with men, Barcelona (Spain), October 2016 and January $2017(\mathrm{n}=8)$

\begin{tabular}{|c|c|c|c|c|c|c|c|c|c|c|}
\hline Case & $\begin{array}{l}\text { Age group } \\
\text { (years) } \\
\text { origin }\end{array}$ & Symptoms & $\begin{array}{l}\text { Year of } \\
\text { diagnosis }\end{array}$ & $\begin{array}{l}\text { Microscopic } \\
\text { analysis of } \\
\text { stool }\end{array}$ & $\begin{array}{c}\text { Entamoeba } \\
\text { histolytica } \\
\text { antigen } \\
\text { in stool } \\
\text { (ELISA) }\end{array}$ & $\begin{array}{l}\text { Faecal } \\
\text { cultures }\end{array}$ & $\begin{array}{c}\text { Entamoeba } \\
\text { histolytica } \\
\text { serological } \\
\text { test (ELISA) }\end{array}$ & $\begin{array}{l}\text { HIV status } \\
\left(C D_{4}, \text { VL) }\right.\end{array}$ & $\begin{array}{c}\text { Concurrent } \\
\text { STI }\end{array}$ & $\begin{array}{l}\text { Response } \\
\text { to } \\
\text { treatment }\end{array}$ \\
\hline A & $50-59$, UK & $\begin{array}{c}\text { Diarrhoea } \\
\text { with mucus, } \\
\text { abdominal pain }\end{array}$ & 2016 & $\begin{array}{c}\text { Entamoeba } \\
\text { sp. } \\
\text { trophozoites }\end{array}$ & Positive & $\begin{array}{l}\text { Shigella } \\
\text { flexneri }\end{array}$ & Negative & $\begin{array}{l}\text { Positive } \\
(750,<25)\end{array}$ & No & Recurrence \\
\hline B & 30-39, UK & $\begin{array}{c}\text { Fever, } \\
\text { abdominal pain, } \\
\text { dysentery, } \\
\text { proctitis }\end{array}$ & 2016 & Negative & Positive & $\begin{array}{l}\text { Shigella } \\
\text { flexneri }\end{array}$ & Negative & Negative & $\begin{array}{l}\text { Anorectal } \\
\text { herpes } \\
\text { simplex } \\
\text { virus } \\
\text { infection }\end{array}$ & Cure \\
\hline C & $\begin{array}{l}20-29, \text { The } \\
\text { Netherlands }\end{array}$ & $\begin{array}{l}\text { Dysentery, } \\
\text { proctitis }\end{array}$ & 2016 & $\begin{array}{l}\text { Entamoeba } \\
\text { sp. } \\
\text { trophozoites }\end{array}$ & Positive & Negative & Negative & Negative & $\begin{array}{l}\text { Anorectal } \\
\text { syphilis } \\
1 \text { month } \\
\text { before }\end{array}$ & Cure \\
\hline D & $\begin{array}{c}40-49 \\
\text { Spain }\end{array}$ & Proctitis & 2016 & Negative & Positive & Negative & Negative & Negative & No & Recurrence \\
\hline$E$ & $\begin{array}{l}\text { 20-29, } \\
\text { Spain }\end{array}$ & $\begin{array}{c}\text { Diarrhoea } \\
\text { with mucus, } \\
\text { abdominal pain }\end{array}$ & 2017 & Negative & Positive & Negative & NA & Negative & $\begin{array}{c}\text { Rectal } \\
\text { clahmydial } \\
\text { infection }\end{array}$ & Cure \\
\hline $\mathrm{F}$ & $\begin{array}{l}\text { 40-49, } \\
\text { Uruguay }\end{array}$ & $\begin{array}{l}\text { Diarrhoea, } \\
\text { abdominal pain }\end{array}$ & 2017 & $\begin{array}{c}\text { Entamoeba } \\
\text { sp. } \\
\text { trophozoites }\end{array}$ & Positive & Negative & NA & $\begin{array}{l}\text { Positive } \\
(664,<25)\end{array}$ & No & Cure \\
\hline G & $\begin{array}{c}\text { 30-39, } \\
\text { Venezuela }\end{array}$ & $\begin{array}{c}\text { Diarrhoea } \\
\text { with mucus, } \\
\text { abdominal pain }\end{array}$ & 2017 & $\begin{array}{l}\text { Entamoeba } \\
\text { sp. } \\
\text { trophozoites }\end{array}$ & Positive & Negative & NA & $\begin{array}{l}\text { Positive } \\
\quad(520, \\
497.000)\end{array}$ & $\begin{array}{l}\text { Recent HIV } \\
\text { infection }\end{array}$ & Cure \\
\hline $\mathrm{H}$ & $\begin{array}{l}\text { 40-49, } \\
\text { Spain }\end{array}$ & $\begin{array}{c}\text { Diarrhoea } \\
\text { with mucus, } \\
\text { proctalgia }\end{array}$ & 2017 & $\begin{array}{l}\text { Entamoeba } \\
\text { sp. } \\
\text { trophozoites }\end{array}$ & Positive & Negative & NA & $\begin{array}{c}\text { Positive } \\
(1032,<25)\end{array}$ & $\begin{array}{l}\text { Anorectal } \\
\text { herpes } \\
\text { simplex } \\
\text { virus } \\
\text { infection }\end{array}$ & Recurrence \\
\hline
\end{tabular}

CD4: $\mathrm{CD}_{4}^{+}$T cell count per mm³; M: male; NA: not available; STI: sexually transmitted infection; UK: United Kingdom; VL: viral load in RNA copies per $\mathrm{mL}$.

the detection of E. histolytica-specific antigen in stool, to differentiate it from other non-pathogenic amoebas. Serological tests may help in the diagnosis of invasive amoebiasis [3], but its sensitivity can vary with the type and stage of disease [4] and they can be negative in acute infections, as it happened in the cases reported here.

Since the 1980s, EHI or amoebiasis has been increasingly reported among MSM $[1,2,5]$, particularly those with HIV infection, in developed non-endemic countries such as Australia, Japan, Korea, and Taiwan [6-9]. Several studies that used serological tests, most of them from the 1980 s, reported a seroprevalence of EHI ranging from $1 \%$ to $21 \%$ among MSM in several developed countries, a considerably higher seroprevalence than among heterosexual people (0-7\%) [1,10-12].

Higher rates of $\mathrm{EHI}$ among homosexual men seem to be attributable to the practice of oral-anal sex $[13,14]$, either directly or via sex toys or fellatio, and may reflect high-risk sexual behaviour and multiple exposures. This is supported by reports of high rates of intestinal sexually transmissible infections in MSM who visit sex venues [15]. Our cases had as risk factors the practice of oral-anal sex, patients $A$ and $E$ reported high risk sexual behaviours such as sex parties, and one patient had had sexual contact with a man from India. It is a limitation of this study that our patients were not systematically asked if they had practiced chemsex.

Hung et al. [6] found in Taiwan that invasive amoebiasis, high antibody titres in indirect haemagglutination and faecal colonisation with $E$. histolytica were more common in HIV-infected than in HIV-uninfected persons. In Japan, nearly $80 \%$ of the 600 cases of amoebiasis diagnosed every year occurred in MSM [16] and invasive amoebiasis was associated with syphilis and HIV infection [17-19]. Four of our patients had an HIV infection, one had also recently been diagnosed with syphilis and two had a co-infection with S. flexneri, another sexually transmissible enteric infection described in MSM [13,15]. It remains unclear whether HIV-related immunosuppression is a risk factor for amoebiasis or if this association may reflect a greater risk of sexual exposure. Our four patients with HIV had CD4+-T cell 
counts above $500 / \mathrm{mm}_{3}$ and only one had a detectable viral load, but five had other STIs. Thus amoebiasis was probably the result of high risk behaviours that are common in HIV-positive MSM.

In Spain, endemic amoebiasis has been virtually eradicated in the last century after improvements in water infrastructure, and most cases are imported from endemic areas. To best of our knowledge, there are no previous published reports of cases of invasive amoebiasis in MSM in Barcelona. Given that a disease outbreak is defined by the World Health Organization as the occurrence of cases of disease in excess of what would normally be expected in a defined community, geographical area or season, we should consider these two clusters of EHI an outbreak in the MSM population [20]. It is noteworthy that two cases coinfected with $S$. flexneri had recently travelled to the UK where a prolonged outbreak of shigellosis among MSM had been noted [21]. Moreover, an increasing trend in shigellosis cases was also noted in MSM in Spain [22]. This may reflect the risk of enteric infections spreading across Europe through sexual transmission in such a highly mobile population, as it has happened with recent outbreaks of hepatitis A [23-25].

Outbreaks of amoebiasis like the one we report are of public health and clinical concern because EHI may be spread in the MSM population and can cause severe disease. Hence surveillance networks and notification systems are essential. In addition, asymptomatic infection should be tested for and treated because of its potential to progress to an invasive disease [4], although it can be difficult to carry out contact tracing in order to interrupt transmission. Moreover, there is a risk of further spread into non-MSM populations, as reported in Tokyo, where there were increased rates of E. histolytica seropositivity in heterosexual women [26], and in Canada, where a sexually transmitted cluster of amoebiasis in heterosexuals and female homosexuals were described [5]. If the need arises, molecular typing could be helpful to better define outbreaks. Periodic screening using molecular techniques in rectal swabs could be useful in preventing the spread of the infection, especially in MSM populations with high-risk behaviours. It has been shown to be a feasible and acceptable method for detecting gastrointestinal infections in previous studies [27].

\section{Conclusion}

In order to prevent morbidity and transmission, physicians should be aware of amoebiasis as an emerging infection in the MSM population in non-endemic countries, with a greater risk in HIV-infected individuals. Therefore, MSM who are diagnosed with EHI or other enteric infections should be referred for STI and HIV testing, but unless the infection is recognised as being sexually transmitted, this may not happen. Moreover, information campaigns may target risk groups and relevant venues.
Conflict of interest

None declared.

Authors' contributions

Laura Escolà-Vergé, Maider Arando, Roger Rovira, Martí Vall and María-Jesús Barberá acquired clinical and laboratory data. Laura Escolà-Vergé drafted the manuscript. Maider Arando, Roger Rovira, Martí Vall, Mateu Espasa, Elena Sulleiro, Pere Armengol, Francesc Zarzuela and María-Jesús Barberá reviewed the manuscript. All authors approved the final version.

\section{References}

1. Hung CC, Chang SY, Ji DD. Entamoeba histolytica infection in men who have sex with men.Lancet Infect Dis. 2012;12(9):72936. DOI: 10.1016/S1473-3099(12)70147-0 PMID: 22917103

2. Stark D, van Hal SJ, Matthews G, Harkness J, Marriott D. Invasive amebiasis in men who have sex with men, Australia.Emerg Infect Dis. 2008;14(7):1141-3. DOI: 10.3201/ eid1407.080017 PMID: 18598643

3. Singh A, Houpt E, Petri WA. Rapid Diagnosis of Intestinal Parasitic Protozoa, with a Focus on Entamoeba histolytica. Interdiscip Perspect Infect Dis. 2009;2009:547090. DOI: 10.1155/2009/547090 PMID: 19584941

4. Haque R, Huston CD, Hughes M, Houpt E, Petri WA Amebiasis.N Engl J Med. 2003;348(16):1565-73. DOI: 10.1056/ NEJMra022710 PMID: 12700377

5. Salit IE, Khairnar K, Gough K, Pillai DR. A possible cluster of sexually transmitted Entamoeba histolytica: genetic analysis of a highly virulent strain.Clin Infect Dis. 2009;49(3):346-53. DOI: 10.1086/600298 PMID: 19580413

6. Hung CC, Deng HY, Hsiao WH, Hsieh SM, Hsiao CF, Chen MY, et al. Invasive amebiasis as an emerging parasitic disease in patients with human immunodeficiency virus type 1 infection in Taiwan. Arch Intern Med. 2005;165(4):409-15. DOI: 10.1001/ archinte.165.4.409 PMID: 15738369

7. Tsai JJ, Sun HY, Ke LY, Tsai KS, Chang SY, Hsieh SM, et al. Higher seroprevalence of Entamoeba histolytica infection is associated with human immunodeficiency virus type 1 infection in Taiwan. Am J Trop Med Hyg. 2006;74(6):1016-9. PMID: 16760513

8. James R, Barratt J, Marriott D, Harkness J, Stark D. Seroprevalence of Entamoeba histolytica infection among men who have sex with men in Sydney, Australia.Am J Trop Med Hyg. 2010;83(4):914-6. DOI: 10.4269/ajtmh.2010.10-0231 PMID: 20889891

9. Hung CC, Ji DD, Sun HY, Lee YT, Hsu SY, Chang SY, et al. Increased risk for Entamoeba histolytica infection and invasive amebiasis in HIV seropositive men who have sex with men in Taiwan. PLoS Negl Trop Dis. 2008;2(2):e175. DOI: 10.1371/ journal.pntd.0000175 PMID: 18301730

10. Aceti A, Pennica A, Ippolito G, Moretto D, Rezza G, Titti F, et al. Antiamebic antibodies in homosexual men. N Engl J Med. 1987;316(11):692. DOI: 10.1056/NEJM198703123161112 PMID: 2881205

11. Takeuchi T, Okuzawa E, Nozaki T, Kobayashi S, Mizokami M, Minoshima N, et al. High seropositivity of Japanese homosexual men for amebic infection. J Infect Dis. 1989;159(4):808. DOI: 10.1093/infdis/159.4.808 PMID: 2538524

12. Takeuchi T, Miyahira Y, Kobayashi S, Nozaki T, Motta SR, Matsuda J. High seropositivity for Entamoeba histolytica infection in lapanese homosexual men: further evidence for the occurrence of pathogenic strains.Trans R Soc Trop Med Hyg. 1990;84(2):250-1. . Available from: DOI: 10.1016/00359203(90)90275-J PMID: 2389318

13. Moran P, Ramos F, Ramiro M, Curiel O, González E, Valadez $A$, et al. Entamoeba histolytica and/or Entamoeba dispar: infection frequency in HIV+/AIDS patients in Mexico city. Exp Parasitol. 2005;110(3):331-4. DOI: 10.1016/j. exppara.2005.03.023 PMID: 15955334

14. Ortega HB, Borchardt KA, Hamilton R, Ortega P, Mahood J. Enteric pathogenic protozoa in homosexual men from San Francisco.Sex Transm Dis. 1984;11(2):59-63. DOI: 10.1097/00007435-198404000-00001 PMID: 6087479

15. O’Sullivan B, Delpech V, Pontivivo G, Karagiannis T, Marriott D, Harkness J, et al. Shigellosis linked to sex venues, 
Australia. Emerg Infect Dis. 2002;8(8):862-4. DOI: 10.3201/ eido808.010534 PMID: 12141976

16. Nozaki T, Kobayashi S, Takeuchi T, Haghighi A. Diversity of clinical isolates of Entamoeba histolytica in Japan. Arch Med Res. 2006;37(2):277-9. DOI: 10.1016/j.arcmed.2005.09.010 PMID: 16380332

17. Ohnishi K, Kato Y, Imamura A, Fukayama M, Tsunoda T, Sakaue $Y$, et al. Present characteristics of symptomatic Entamoeba histolytica infection in the big cities of Japan. Epidemiol Infect. 2004;132(1):57-60. DOI: 10.1017/S0950268803001389 PMID: 14979590

18. Nagata N, Shimbo T, Akiyama J, Nakashima R, Nishimura S, Yada T, et al. Risk factors for intestinal invasive amebiasis in Japan, 2003-2009. Emerg Infect Dis. 2012;18(5):717-24. DOI: 10.3201/eid1805.111275 PMID: 22515839

19. Lo YC, Ji DD, Hung CC. Prevalent and incident HIV diagnoses among Entamoeba histolytica-infected adult males: a changing epidemiology associated with sexual transmission--Taiwan, 2006-2013.PLoS Negl Trop Dis. 2014;8(10):e3222. DOI: 10.1371/ journal.pntd.0003222 PMID: 25299178

20. World Health Organization (WHO). Disease outbreaks. Geneva: WHO. [Accessed: 27 March 2017]. Available from: http://www. who.int/topics/disease_outbreaks/en/

21. Simms I, Field N, Jenkins C, Childs T, Gilbart VL, Dallman TJ, et al. Intensified shigellosis epidemic associated with sexual transmission in men who have sex with men--Shigella flexneri and S. sonnei in England, 2004 to end of February 2015. Euro Surveill. 2015;20(15):21097. DOI: 10.2807/1560-7917. ES2015.20.15.21097 PMID: 25953129

22. Culqui DR, García-de-Olalla-Rizo P, Alva-Chavez KP, Lafuente $S$, Rius $C$, de Simón $M$, et al. [Analysis of the epidemiological pattern of Shigellosis in Barcelona between 1988 and 2012: Is it an emerging sexually transmitted infection?]. Enferm Infecc Microbiol Clin. 2015;33(6):379-84. DOI: 10.1016/j. eimc.2014.09.013 PMID: 25487603

23. Werber D, Michaelis K, Hausner M, Sissolak D, Wenzel J, Bitzegeio J, et al. Ongoing outbreaks of hepatitis A among men who have sex with men (MSM), Berlin, November 2016 to January 2017 - linked to other German cities and European countries. Euro Surveill. 2017;22(5):30457. DOI: 10.2807/15607917.ES.2017.22.5.30457 PMID: 28183391

24. Freidl GS, Sonder GJ, Bovée LP, Friesema IH, van Rijckevorsel GG, Ruijs WL, et al. Hepatitis A outbreak among men who have sex with men (MSM) predominantly linked with the EuroPride, the Netherlands, July 2016 to February 2017. Euro Surveill. 2017;22(8):30468. DOI: 10.2807/1560-7917. ES.2017.22.8.30468 PMID: 28251892

25. Beebeejaun K, Degala S, Balogun K, Simms I, Woodhall SC, Heinsbroek E, et al. Outbreak of hepatitis A associated with men who have sex with men (MSM), England, July 2016 to January 2017. Euro Surveill. 2017;22(5):30454. DOI: 10.2807/1560-7917.ES.2017.22.5.30454 PMID: 28183392

26. Suzuki J, Kobayashi S, Iku I, Murata R, Yanagawa Y, Takeuchi T. Seroprevalence of Entamoeba histolytica infection in female outpatients at a sexually transmitted disease sentinel clinic in Tokyo, Japan.Jpn J Infect Dis. 2008;61(3):175-8.PMID: 18503164

27. Hughes G, Silalang P, Were J, Patel H, Childs T,

Alexander $S$, et al. Prevalence and characteristics of gastrointestinal infections in men who have sex with men diagnosed with rectal chlamydia infection in the UK: an 'unlinked anonymous' cross-sectional study. Sex Transm Infect. 2017; Sextrans-2016-053057. DOI: 10.1136/ sextrans-2016-053057 PMID: 28360379

\section{License and copyright}

This is an open-access article distributed under the terms of the Creative Commons Attribution (CC BY 4.0) Licence. You may share and adapt the material, but must give appropriate credit to the source, provide a link to the licence, and indicate if changes were made.

This article is copyright of the authors, 2017. 